\title{
EVALUATION OF CHEMICAL ATTRIBUTES OF SOIL UNDER DIFFERENT MANAGEMENT SYSTEMS OF SUGARCANE IN AN AREA OF EXPANSION
}

\author{
AVALIAÇÃO DE ATRIBUTOS QUÍMICOS DO SOLO SUBMETIDO A DIFERENTES \\ MANEJOS EM ÁREA DE EXPANSÃO DE CANA-DE-AÇÚCAR
}

\author{
Regina Maria Quintão LANA ${ }^{1}$; Lucas Oliveira Ribeiro MAIA ${ }^{2}$; \\ Ana Carolina Pereira de VASCONCELOS ${ }^{3}$; Emmerson Rodrigues de MORAES ${ }^{3}$; \\ Thiago Prudente SIQUEIRA ${ }^{4}$; Adriane de Andrade SILVA ${ }^{5}$
}

1. Professor, Doctor, In Institute of Agricultural Sciences of the Federal University of Uberlandia, Uberlandia, MG, Brazil. rmqlana@terra.com.br; 2. Agronomist in the Institute of Agricultural Sciences of the Federal University of Uberlandia, Uberlandia, MG, Brazil; 3. Doctor's Degree in the Institute of Agricultural Sciences of the Federal University of Uberlandia, Uberlandia, MG, Brazil; 4. Master's Degree in the Institute of Agricultural Sciences of the Federal University of Uberlandia, Uberlandia, MG, Brazil; 5. Professor, Doctor, In Institute of Agricultural Sciences of the Federal University of Uberlandia, Uberlandia, MG, Brazil.

\begin{abstract}
In the area of expansion, where if you have restriction on fertility, soil preparation has contributed considerably to the improvement of the physical, chemical and water conditions of soils and, consequently, to the proper development of culture of sugarcane. The aim of this study was to evaluate the effect of different management techniques on the availability of nutrients in soil in an area of expansion of sugarcane, formerly with Brachiaria decumbens, in the Cerrado region. The experiment was conducted using the CTC 2 variety at Jalles Machado mill in Goianésia, GO. The experiment was established in a randomized block design, with six treatments and four replications. Chemical attributes of soil were evaluated at depths of 0-20, 20-40 and 40-60 cm. Significant differences were found among depths for all analyzed attributes. Adopted management systems influenced chemical attributes and the availability of nutrients for plants. Invertion of soil through plowing and harrowing is extremely beneficial to carry out soil amendment in the first year of cultivation, improving the incorporation and effectiveness of the corrective. The adoption of no-tillage system did not prove to be the best option for the first year of sugarcane cultivation, hindering the incorporation of the corrective.
\end{abstract}

KEYWORDS: Nutrition of plants. Soil preparation. Saccharum officinarum.

\section{INTRODUCTION}

Sugarcane is grown on large areas and it is among the most important crops in the world, due to its multiple use by various sectors. Since 2003, the state of Goiás has been standing out in the process of expansion of cultivated areas of sugarcane and it is now the second in the ranking of Brazilian producers, only behind the state of São Paulo (BRAZIL, 2015).

The sugarcane yield in the Cerrado region is lower than that recorded in São Paulo, which accounts for $53 \%$ of the area planted with sugarcane in the country. In the 2009-2013 period, the average productivity of stems in the Midwest was 77 tons per hectare comparied with 82 tons per hectare in São Paulo (CASTELÕES, 2015).

Nowaday, worldwide, one can observe the concern regarding issues related to the environment. Thus, it is increasing the search for production technologies that enable the development of crops that provide food and energy with the lowest possible environmental impact. In this sense, sugarcane is a culture which produces per unit of area a large amount of biomass and it can be used to produce food and energy demand.

Brazil has been a world leader in this sector for a few years now. In the second survey conducted by the National Supply Company (CONAB), for the 2014/2015 crop, the forecast is about 651.5 million tons from a total area of 9,098,030 hectares with an average estimated productivity of $72,444 \mathrm{~kg} \mathrm{ha}^{-1}$. From this, 302.08 million tons should be used for the production of sugar, which should generate approximately 38.25 million tons of the product. The remaining 357.02 million tons will be used for the production of ethanol, for a total of somewhat around 27.62 billion liters (CONAB, 2014).

The sugarcane is expanding its areas mainly occupying the seating areas previously occupied by pastures. According to Inácio; Santos (2013), the cultivation of sugarcane is overlapping in relation to other agricultural activities such as livestock, coffee and soybeans. These authors say that expansion areas are those in previous crops were destined for other crops and the current crop are being cultivated with sugarcane and will be available for the first time harvest. Crops of sugarcane which were converted into another use for a period equal to or 
greater than two seasons and returned to be planted with sugarcane also be included in this class.

With the expansion of sugarcane production area, the cerrado has gained importance, increasing domestic production considerably. Unlike traditional production areas in the cerrado, there is the need for corrective and heavy fertilization to achieve adequate productivity. Fertilizer costs account for about $17-25 \%$ of planting costs (ROSSETTO et al., 2010). Therefore, the big question is what soil preparation must be adopted to improve the productivity and sustainability of sugarcane. According to MORAES (2011) the conventional tillage and the conservation management traditionally called "no-till" require some adaption for sugarcane, because this culture is semi-permanent, rotating expected crops in no-till does not occur. Instead, a "minimum-till" is used leaving haulm after sugarcane harvest for the conservation system.

Benedini; Conde (2008), report that exaggerated soil disturbance in the traditional preparation affect the management of rain water, making it difficult to infiltration and increasing runoff, which leads to erosion. On the other hand, the production systems which prioritizes maintaining the stability of the soil, as no-till, minimum tillage and minimum tillage, among others, tend to predominate in these areas, but with adaptations as removal of terraces in preparation for the entry of mechanized harvesting, although not recommended.

Foltran (2008), in lime application study, calcium silicate and gypsum ratoon of sugarcane without straw removal by burning, says that results of research on the application of corrective surface and without incorporation in tillage have shown promising results, however, are restricted to grain crops and are scarce in the literature studies that report the application of correctives in the culture of raw cane. Similarly, there are research related to the expansion of sugarcane for degraded pastures in the Cerrado using tillage.

The soil preparation is aimed at least minimize the adverse conditions to obtain the maximum economic yield. For this, one must consider the physical, chemical, biological and soil external factors such as weed infestation. Areas without physical, chemical and biological limitations can achieve good productivity much more economically, thus generating higher profits through the adoption of no-tillage (VITTI; MAZZA, 2002).

In order to study the effect of soil preparation and direct planting systems on soil chemical characteristics, soil chemical properties were evaluated which were submitted to five types of soil preparation and no-tillage system on a sugarcane expansion area in the cerrado region.

\section{MATERIAL AND METHODS}

This study was conducted on the property of Jalles Machado SA mill, in Goianésia-GO, at coordinates $15^{\circ} 10^{\prime} \mathrm{S}$ latitude and $49^{\circ} 15^{\prime} \mathrm{W}$ longitude, at $640 \mathrm{~m}$ of altitude, in an area where previously over 10 years is grown with pasture with Brachiaria decumbens under extensive cultivation and no corrections.

The local climate is classified as Aw (megathermal) or tropical savanna, according to the Köppen classification, with dry winters and rainy summers and average temperatures of $23.7^{\circ} \mathrm{C}$ and $25.4^{\circ} \mathrm{C}$ respectively. The average annual rainfall is $1500 \mathrm{~mm}$.

The soil was classified as red-yellow latosol (EMBRAPA, 2006), presenting the following chemical characteristics at the depths of 0-20 and 21-40 cm respectively: $\mathrm{pH}(\mathrm{H} 2 \mathrm{O})$ of 4.01 and 3.97; 16.2 and $10.4 \mathrm{~kg} \mathrm{dag}^{-1}$ of organic matter $(\mathrm{OM}) ; 78$ and $19.2 \mathrm{mg} \mathrm{dm}^{-3}$ of potassium (K); 0.45 and 0.23 cmolc $\mathrm{dm}^{-3}$ of calcium (Ca); 0.29 and 0.15 cmolc $\mathrm{dm}^{-3}$ of magnesium $(\mathrm{Mg}) ; 8.25$ and $8.7 \mathrm{cmolc} \mathrm{dm}^{-3}$ of potential acidity $(\mathrm{H}+\mathrm{AL}) ; 1.65$ and $2 \mathrm{cmolc} \mathrm{dm}$ ${ }^{3}$ of aluminum (Al); 0.93 and $0.43 \mathrm{cmolc} \mathrm{dm}^{-3}$ of the sum of bases (SB); 9.19 and $9.12 \mathrm{cmolc} \mathrm{dm}^{-3}$ of potential cation exchange capacity at $\mathrm{pH} 7(\mathrm{~T}) ; 2.58$ and $2.43 \mathrm{cmolc} \mathrm{dm}^{-3}$ of effective cation exchange capacity (T); 63 and $82 \%$ of aluminum saturation (m); and base saturation $\mathrm{V} \%=10.25$ and $4.8 \%$.

The implementation of the experiment was carried out in January 2009, with the demarcation of the area, desiccation and soil management, thus defining the treatments. Evaluations were conducted from January 2009 to July 2010, when sugarcane was harvested and relevant assessments took place.

The experiment had a randomized blocks design, with six treatments and four replications. The total area of the experiment was $34505 \mathrm{~m}^{2}$. Each replication was comprised of six plots, each 50 $\mathrm{m}$ long and $19.5 \mathrm{~m}$ wide, with 13 sugarcane lines spaced $1,5 \mathrm{~m}$. Carriers of $5 \mathrm{~m}$ in width were made to maneuver machinery.

The following soil preparation were used to define the treatments: Treatment 1: desiccation + lime + plowing + harrowing; Treatment 2: lime + plowing + harrowing; Treatment 3: lime + harrowing + plowing + harrowing; Treatment 4: desiccation + lime + direct planting; Treatment 5: 
desiccation + lime + subsoiler; Treatment 6: harrowing + lime + plowing + harrowing.

The following treatments were performed in different systems: 1 - desiccation - broad spectrum herbicides, glyphosate plus 2, $4-\mathrm{D}$, at the doses of 3.0 and $2.0 \mathrm{~L} \mathrm{~h}^{-1}$, respectively; 2 - lime - a dolomitic limestone with PRNT of $85 \%$ at a dose of $1.5 \mathrm{t} \mathrm{ha}^{-1}$, distributed evenly in all treatments; 3 - ploughing performed with a moldboard plow at an effective depth of 35-40 cm; 4 - harrowing - an intermediate harrow/leveler was used reaching depths from 15 to $20 \mathrm{~cm} ; 5$ - subsoiler - a subsoiler was used reaching depth of $40 \mathrm{~cm}$; 6 - no-tillage system - furrows using a trencher were made reaching depths of 30 $40 \mathrm{~cm}$. Gypsum application took place after the implementation of all treatments. The delivered dose was $800 \mathrm{~kg} \mathrm{ha}^{-1}$, distributed by throwing, one for all treatments.

On April $24^{\text {th }}, 2009$ sugarcane was planted manually into furrows $35-40 \mathrm{~cm}$ deep using a furrower with density of $15-20$ of buds $\mathrm{m}^{-1}$. The variety CTC 2 was selected. After the distribution of sets, the coverage was made.

Fertilization was done using $250 \mathrm{~kg} \mathrm{ha}^{-1}$ of monoammonium phosphate (MAP). In addition to that a top-dressing fertilization was performed on 05 September using a $05-00-13+0.3 \% \mathrm{Zn}+0.3 \% \mathrm{~B}$ liquid formula in the amount of $1000 \mathrm{~L} \mathrm{ha}^{-1}$.
In July 2010 after the harvest, soil samplings were taken at depths of 0-20 cm, 20-40 $\mathrm{cm}$ and 40-60 cm, which were later submitted to analysis in the laboratory of soil analysis at the Universidade Federal de Uberlândia (LABAS / UFU). The following contents were analyzed: Phosphorus (P), potassium (K), sulfur $(\mathrm{S})$, calcium $(\mathrm{Ca})$, magnesium $(\mathrm{Mg})$, copper $(\mathrm{Cu})$, iron $(\mathrm{Fe})$, zinc $(\mathrm{Zn})$, manganese $(\mathrm{Mn}), \mathrm{pH}$ in $\mathrm{H}_{2} \mathrm{O}$, organic matter $(\mathrm{OM})$, exchangeable acidity $(\mathrm{Al} 3+)$; total acidity $(\mathrm{H}$ $+\mathrm{Al})$; aluminum saturation $(\mathrm{m} \%)$; base saturation (V\%), according to the methodology of EMBRAPA (2009).

The results were submitted to the ShapiroWilk normality test for the distribution of residuals, and Levene's homogeneity test for the variances, all at $1 \%$ of probability. The data without normal distribution and heterogeneity were subjected to data transformation with square root of $x+0.5$. Analysis of variance was taken by $F$ test at 1 and $5 \%$ of probability. Subsequently, the averages were compared by Tukey test $(\mathrm{p} \leq 0,01$ and 0,05$)$.

\section{RESULTS AND DISCUSSION}

The values of soil chemical properties after harvesting of sugarcane at three different depths are presented in Table 1.

Table 1. Values of sulfur $(\mathrm{S})$, calcium $(\mathrm{Ca})$, magnesium $(\mathrm{Mg})$, potassium $(\mathrm{K})$, potential acidity $(\mathrm{H}+\mathrm{Al})$, exchangeable acidity $(\mathrm{Al})$, effective $\mathrm{CEC}(\mathrm{t})$, potential CEC $(\mathrm{t})$, base saturation $(\mathrm{V} \%)$, aluminum saturation $(\mathrm{m} \%)$, sum of bases $(\mathrm{SB})$ and organic matter $(\mathrm{OM})$ at three depths under different soil tillage systems.

\begin{tabular}{|c|c|c|c|c|c|c|c|c|}
\hline \multirow{3}{*}{$\Gamma 1$} & \multirow{2}{*}{$\mathrm{T} 2$} & \multicolumn{4}{|c|}{ 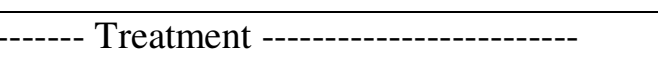 } & \multicolumn{3}{|c|}{------- Depth ------ } \\
\hline & & $\mathrm{T} 3$ & $\mathrm{~T} 4$ & T5 & T6 & $0-20$ & $21-40$ & $41-60$ \\
\hline & \multicolumn{8}{|c|}{$\mathrm{OM}\left(\mathrm{dag} \mathrm{kg}^{-1}\right) \mathrm{CV}(\%)=13.56$} \\
\hline $1.41 \mathrm{ab}$ & $1.42 \mathrm{ab}$ & $1.55 \mathrm{a}$ & $1.23 \mathrm{~b}$ & $1.49 \mathrm{a}$ & $1.49 \mathrm{a}$ & $88 \mathrm{a}$ & $47 \mathrm{~b}$ & $0.95 \mathrm{c}$ \\
\hline \multicolumn{9}{|c|}{$\mathrm{K}\left(\mathrm{mg} \mathrm{dm}^{-3}\right) \mathrm{CV}(\%)=11.41 *$} \\
\hline $50 \mathrm{ab}$ & $16 \mathrm{a}$ & $0.08 \mathrm{a}$ & $35.66 \mathrm{~b}$ & $50.58 \mathrm{a}$ & $45.83 \mathrm{ab}$ & $79 \mathrm{a}$ & $42.33 \mathrm{~b}$ & $31.29 \mathrm{c}$ \\
\hline \multicolumn{9}{|c|}{$\mathrm{S}-\mathrm{SO}_{4}\left(\mathrm{cmolc} \mathrm{dm}^{3}\right) \mathrm{CV}(\%)=37.77^{*}$} \\
\hline $3 \mathrm{a}$ & $5 \mathrm{~b}$ & $40.66 \mathrm{a}$ & $16.16 \mathrm{ab}$ & $29.16 \mathrm{a}$ & $32.00 \mathrm{a}$ & $24.83 \mathrm{ab}$ & $30.29 \mathrm{a}$ & $1 \mathrm{~b}$ \\
\hline \multicolumn{9}{|c|}{$\mathrm{Ca}\left(\mathrm{cmolc} \mathrm{dm}^{-3}\right) \mathrm{CV}(\%)=16.42^{*}$} \\
\hline $0.71 \mathrm{ab}$ & $0.32 \mathrm{~b}$ & $1.28 \mathrm{a}$ & $0.50 \mathrm{ab}$ & $0.80 \mathrm{a}$ & $0.87 \mathrm{a}$ & $5 \mathrm{a}$ & $0.62 \mathrm{~b}$ & $0.37 \mathrm{c}$ \\
\hline \multicolumn{9}{|c|}{$\mathrm{Mg}\left(\mathrm{cmolc} \mathrm{dm}^{3}\right) \mathrm{CV}(\%)=48.03$} \\
\hline $33 \mathrm{bc}$ & c 22 & $0.59 \mathrm{a}$ & $0.27 \mathrm{bc}$ & $0.38 \mathrm{bc}$ & $0.47 \mathrm{abc}$ & 066 . & $0.30 \mathrm{~b}$ & $0.16 \mathrm{c}$ \\
\hline \multicolumn{9}{|c|}{$\mathrm{Al}\left(\mathrm{cmolc} \mathrm{dm}-{ }^{3}\right) \mathrm{CV}(\%)=8.43^{*}$} \\
\hline $\mathrm{ab}$ & $b$ & $1.34 \mathrm{a}$ & $1.73 \mathrm{ab}$ & $1.65 \mathrm{ab}$ & $1.59 \mathrm{ab}$ & $1.29 \mathrm{a}$ & $6 \mathrm{~b}$ & $1.73 \mathrm{~b}$ \\
\hline \multicolumn{9}{|c|}{$\mathrm{H}+\mathrm{Al}\left(\mathrm{cmolc} \mathrm{dm}^{3}\right) \mathrm{CV}(\%)=7.29 *$} \\
\hline $86 \mathrm{a}$ & $6.60 \mathrm{a}$ & $5.95 \mathrm{a}$ & $5.95 \mathrm{a}$ & $6.49 \mathrm{a}$ & $6.10 \mathrm{a}$ & 78 & $85 \mathrm{~b}$ & $5.87 \mathrm{a}$ \\
\hline \multicolumn{9}{|c|}{$\mathrm{t}\left(\mathrm{cmolc} \mathrm{dm-}{ }^{3}\right) \mathrm{CV}(\%)=4.97 *$} \\
\hline $.04 \mathrm{bc}$ & $7.28 \mathrm{c}$ & $7.96 \mathrm{a}$ & $6.82 \mathrm{bc}$ & $7.80 \mathrm{abc}$ & $7.56 \mathrm{ab}$ & $7.86 \mathrm{a}$ & $7.88 \mathrm{~b}$ & $6.48 \mathrm{c}$ \\
\hline \multicolumn{9}{|c|}{$\mathrm{T}\left(\mathrm{cmolc} \mathrm{dm}^{-}{ }^{3}\right) \mathrm{CV}(\%)=5.61^{*}$} \\
\hline $2.78 \mathrm{a}$ & $2.52 \mathrm{a}$ & $3.34 \mathrm{a}$ & $2.59 \mathrm{a}$ & $2.97 \mathrm{a}$ & $3.05 \mathrm{a}$ & 3.39 & $2.89 \mathrm{a}$ & $2.35 \mathrm{~b}$ \\
\hline
\end{tabular}




\begin{tabular}{|c|c|c|c|c|c|c|c|c|}
\hline \multicolumn{9}{|c|}{$\mathrm{SB}\left(\mathrm{cmolc} \mathrm{dm}^{-}{ }^{3}\right) \mathrm{CV}(\%)=14.73^{*}$} \\
\hline $1.17 \mathrm{bc}$ & $0.67 \mathrm{c}$ & $2.00 \mathrm{a}$ & $0.86 \mathrm{bc}$ & $1.31 \mathrm{ab}$ & $1.45 \mathrm{ab}$ & $2.09 \mathrm{a}$ & $1.02 \mathrm{~b}$ & $0.61 \mathrm{c}$ \\
\hline \multicolumn{9}{|c|}{$\mathrm{V} \% \mathrm{CV}(\%)=46.43$} \\
\hline $16.53 \mathrm{abc}$ & $8.96 \mathrm{c}$ & $25.15 \mathrm{a}$ & $12.42 \mathrm{bc}$ & $16.53 \mathrm{abc}$ & $19.00 \mathrm{ab}$ & $7.11 \mathrm{a}$ & $12.93 \mathrm{~b}$ & $9.25 \mathrm{~b}$ \\
\hline $61.71 \mathrm{bc}$ & $74.22 \mathrm{c}$ & $43.81 \mathrm{a}$ & $68.89 \mathrm{bc}$ & $59.30 \mathrm{bc}$ & $56.50 \mathrm{ab}$ & $40.69 \mathrm{a}$ & $66.41 \mathrm{~b}$ & $75.11 b$ \\
\hline
\end{tabular}

Means followed by different letters in the column differ statistically by $\mathrm{F}$ and Tukey test at $5 \%$ probability. * Data processed with $\mathrm{X}+$ 0.5 root. T1: desiccation + lime + plowing + harrowing; T2: lime + plowing + harrowing; T3: lime + harrowing + plowing + harrowing; T4: desiccation + lime + direct planting; T5: desiccation + lime + subsoiler; T6: harrowing + lime + plowing + harrowing.

The most effective way to increase the $\mathrm{Ca}$ concentration in the soil would be to perform other liming after harvest.

Regarding the sulfate anion $\left(\mathrm{S}_{-} \mathrm{SO}_{4}{ }^{-2}\right)$, the T3 treatment showed the best results, from an agricultural point of view. However, it is only statistically different from the T2 treatment. Among the depths, the highest levels were found in the layers of 0-20 and 20-40 cm. Gypsum (13\% S) was applied at a dose of $800 \mathrm{~kg} \mathrm{ha}^{-1}$, which drove $\mathrm{SO}_{4}{ }^{2-}$ to sub-surface layers.

Regarding $\mathrm{Mg}$, the $\mathrm{T} 3$ treatment was the most responsive at a depth of $0-20 \mathrm{~cm}$. There was an increase of over $100 \%$ in the content of this element. The values of $0.59 \mathrm{cmolc}^{-3}$ for T3 and 0.66 cmolc $\mathrm{dm}^{-3}$ at the $0-20 \mathrm{~cm}$ depth are classified as medium (ALVAREZ et al., 1999) which is justified by the low tendency of retention of $\mathrm{Mg}^{2+}$ molecules. The difference between T3 and T2 is only the harrowing operation performed in $\mathrm{T} 3$, which highlights the importance of having a wellstructured soil to make this and other nutrients available for the plants. Regarding depths, the $\mathrm{Mg}$ content more than doubled from the $0-20 \mathrm{~cm}$ layer to the $20-40 \mathrm{~cm}$ layer. As the area was at the time of the experiment under its first year of cultivation, it was expected that in the course of other cuts, a considerable increase in $\mathrm{Mg}$ content would occur due to the application of lime and fertilizers containing this nutrient.

The potential acidity (Table 1) of soil is an essential tool for soil fertility recommendations, which is the basis to calculate the need for liming. In the present study, none of the treatments had a significant difference in the potential acidity levels.

After the correction of soil, the potential acidity value of the $0-20 \mathrm{~cm}$ layer was reduced from 8.25 to $5.76 \mathrm{cmolc} \mathrm{dm}^{-3}$ due to the action of lime. In the $20-40 \mathrm{~cm}$ layer, where agricultural implements do not disturb soil structure much, the reduction was far less significant, from 8.70 to $6.85 \mathrm{cmolc} \mathrm{dm}^{-3}$. Both valuesachieved after the correction are classified as high (ALVAREZ et al. 1999). Regarding the 40-60 cm layer, according to Moraes (2011), reduction of this attribute in this layer may be defined as a direct benefit of the gypsum application, whose function is to make $\mathrm{Al}^{3+}$ unavailable by complexing the sulfate anion $\left(\mathrm{SO}_{4}{ }^{2-}\right)$. This can be directly attributed to the benefits of gypsum, where the function is complex $\mathrm{Al}^{3+}$ by reaction with the anion sulfate $\left(\mathrm{SO}_{4}{ }^{2-}\right)$ (OKORKOV; OKORKOVA, 2013).

Assuming that the need for liming is the amount of correction required to decrease the acidity of the soil (ALVAREZ et al., 1999) and that all treatments received lime and gypsum, it was expected that the potential acidity levels was lower, highlighting the insufficiency of a single application of the correctives, as well as the analysis of $\mathrm{Ca}$, which highlighted the need for another liming after the first year of production. This can also be proved by the $\mathrm{T} 4$ treatment, where there was no mechanical incorporation due to lack of tillage and where the $\mathrm{H}+\mathrm{Al}$ content was similar to the other treatments. A new correction of soil may cause the fall of potential acidity in the soil profiles, which may occur once the negative charges of soil are unblocked, which will be occupied by the essential bases.

In jobs with soil tillage, it is expected that the implements like plows moldboard act until the layer $30 \mathrm{~cm}$. Kaminski et al., (2007), says the lime incorporation occurs in the larger root concentration range, ie up to $20 \mathrm{~cm}$ deep, which when incorporated into the corrective action is more effective. Already Neto et al., (2001) found effect of liming as incorporated by plowing and disking up to $15 \mathrm{~cm}$ deep.

Duiker; Beegle (2006) using moldboard order to incorporate limestone in depth $30-35 \mathrm{~cm}$ noted that, with the addition of limestone, there was an increase in the availability of $\mathrm{Ca}$ and reduction of toxic aluminum, and strategy soil management to improve the environment by deep root growth. These authors reported that soil preparation techniques used in this experiment are efficient for lime incorporation.

The exchangeable acidity values $\left(\mathrm{Al}^{3+}\right)$ (Table 1), even in the best treatment (T3) are still classified as high (ALVAREZ et al., 1999). These amounts are detrimental to productivity and quality 
(POL and BRIX) of sugarcane, which further demonstrates the need of correcting this attribute.

Evaluating the different depths, there is a significant difference in $\mathrm{Al}^{3+}$ amount. In the $0-20 \mathrm{~cm}$ layer the exchangeable aluminum was more complexed, due to the applied lime and management adopted in treatments.

Observing the effective CEC (Table 1) in all treatments, at the three depths and considering that the values are classified as low (below $2.30 \mathrm{cmolc}$ $\mathrm{dm}^{-3}$ ) (ALVAREZ et al., 1999), it is concluded that the possibility of cation $\left(\mathrm{Ca}^{2+}, \mathrm{Mg}^{2+}\right.$ and $\left.\mathrm{K}^{+}\right)$losses due to lixiviation is very large. From a statistical point of view, there was a significant difference amoung treatments, with the T3 treatment showing the best result, which did not differ from T5 and T6 treatments. Another important attribute to be analyzed together with the effective soil CEC is the OM. A soil with low effective CEC tends to have low OM content (NETO et al., 2001).

The effective CEC as well as the potential CEC (CEC at $\mathrm{pH} 7$ ) in all the treatments were low (ALVAREZ et al., 1999), with no statistical difference between them. Regarding the depths, there was a significant difference. The 0-20 and 20$40 \mathrm{~cm}$ layers showed higher amount of neutralized cations $\mathrm{H}^{+}$, leaving more negative charges available for the essential cations.

Watching the aluminum saturation values $(\mathrm{m} \%)$ in Table 1, it can be noticed that the T3 treatment stood out. Still, its ranking was average, with $43.81 \%$ of CEC occupied by $\mathrm{Al}^{3+}$ cations (ALVAREZ et al. 1999). Regarding the depths, the $0-20 \mathrm{~cm}$ layer showed the lowest percentage of $\mathrm{Al}^{3+}$ occupying the soil CEC, with $40.69 \%$.

The percentage of CEC which is occupied by $\mathrm{Al}^{3+}$ reflects the correction efficiency to complex this cation. When the amount of lime is not sufficient, the aluminum saturation values are high; it is, therefore, necessary to perform other liming after the next cut, with the intention to reduce these values.

Another important point to observe about the aluminum saturation is in the $\mathrm{T} 2$ treatment where the highest percentage of CEC occupied by $\mathrm{Al}^{3+}$ cations was observed, indicating a higher concentration of this nutrient in soil. This was due to the lack of soil disturbance in the no-tillage system.

Regarding the base saturation (Table 1), unlike aluminum saturation, a higher percentage leads to a lower amount of $\mathrm{Al}^{3+}$ cations adsorbed to soil CEC. The T3 treatment and 0-20 cm depth was the ones that showed the best results.

In the case of base saturation (V\%), treatments $\mathrm{T} 1, \mathrm{~T} 3, \mathrm{~T} 5$ and $\mathrm{T} 6$ did not differ, however, from an agricultural point of view, the T3 treatment showed higher adsorption of base cations $\left(\mathrm{Ca}^{2+}, \mathrm{Mg}^{2+}\right.$ e $\left.\mathrm{K}^{+}\right)$. The $\mathrm{T} 3$ treatment obtained $25.15 \%$ of $\mathrm{V} \%$, classified as low, and the $\mathrm{T} 6$ treatment obtained $19.00 \%$ of $\mathrm{V} \%$, rated as very low (ALVAREZ et al. 1999). With a harrowing performed prior to liming, it was expected that the T6 treatment would present a higher percentage than treatment T3. However, these results show that the mechanical soil tillage operations were more efficient in these two treatments and, for a large majority of the evaluated attributes, these were the ones that showed the best results.

For the culture of sugarcane, the suitable bases saturation is $60 \%$, which demonstrates the need of soil correction with successive crops due to the extraction of bases by sugarcane.

With regard to the OM content (Table 1) the T3 treatment obtained the best result with a value of $1.55 \mathrm{~kg} \mathrm{dag}^{-1}$. This result did not differ statistically from the other treatments, except for the T4 treatment $\left(1.23 \mathrm{dag}_{\mathrm{kg}}^{-1}\right)$. All the values are classified as low (ALVAREZ et al., 1999). A possible explanation for these low levels of soil OM is in its revolving. As a soil layer is revolved, the contact of its particles with the correction becomes more intensive, as well as the contact of the microorganisms with the OM. In this sense, OM decomposition through oxidation becomes faster, thus, its levels will be low in an area which has undergone a high mechanical interference, such as in the treatment of this experiment.

In places where the no-tillage system was adopted a higher content of OM was observed in the upper layers. However, this increase does not usually occur in the early years of the adoption of the NT, but after 6 or 7 years (ALTMANN, 2010; LOPES et al., 2004), which is in agreement with the results obtained in this study, where the $\mathrm{OM}$ in the surface layers is still low.

It is expected that over time, with the incorporation of the straw, the supply of nutrients is effective and can provide great benefits to soil biology and, consequently, to fertility of this. Some authors, like Trivelin et al., (1997), and Fortes et al., (2012) observed that the maintenance of straw and the application of waste from the sugar industry can benefit the soil for nutrient recycling, reducing the use of industrial fertilizers.

In the tillage system, it is known that the preservation of $\mathrm{OM}$ is essential to maintain the productive capacity in tropical environments since it is an important source of nutrients to crops. Compared to conventional tillage system in sugarcane-tillage ensures higher levels of $\mathrm{OM}$ 
resulting in economy and sustainability (ARRUDA et al., 2015).

Contrary to what was presented in Table 1, the T4 treatment should have the highest OM content, since soil revolving operations did not occur, due to the adoption of no-tillage (NT). In addition to the $\mathrm{T} 4$ treatment, $\mathrm{T} 1$ and $\mathrm{T} 5$ treatments, which went through the process of desiccation and subsequent incorporation of crop residues, should also have higher values. However, the assessments were only made in the first year of sugarcane plantations, a period not long enough for a considerable increase of OM, among other soil chemical properties. Silva et al., (2014) observed that the absence of liming the soil and no soil disturbance resulted in a significant reduction in rates of loss of OM.

As for the depth, the surface layer $(0-20 \mathrm{~cm})$ presented the greatest amount of OM (1.88 dag kg$\left.{ }^{1}\right)$, which was statistically different from the other sampled depths.

The absence of tillage and the quantity and quality of the residues of crops in rotation or a succession of cover crops over the years, lead to a gradual increase in OM content, especially in the surface layer (0 to $10 \mathrm{~cm}$ ) (ALTMANN, 2010).

For the culture of sugarcane, an ideal sum of base values is about $2.5 \mathrm{cmolc} \mathrm{dm}^{-3}$. Therefore, none of the treatments achieved such level of SB (Table 1). The treatment which came close to the appropriate value was T3 $\left(2.00 \mathrm{cmolc} \mathrm{dm}^{-3}\right)$, which was not statistically different from T5 (1.31 cmolc $\left.\mathrm{dm}^{-3}\right)$ and T6 (1.45 cmolc $\left.\mathrm{dm}^{-3}\right)$ treatments. The worst result was obtained in the $\mathrm{T} 2$ treatment $(0.67$ cmolc $\mathrm{dm}^{-3}$ ). Regarding the depths, again the 0-20 $\mathrm{cm}$ layer proved to be the most charged with exchangeable cations $\left(\mathrm{Ca}^{2+}, \mathrm{Mg}^{2+}\right.$ e $\left.\mathrm{K}^{+}\right)$, with 2,09 $\mathrm{cmol}_{\mathrm{c}} \mathrm{dm}^{-3}$.

\section{CONCLUSIONS}

The different systems applied on sugarcane expansion area differed in soil chemical properties, as well as the availability of nutrients for plants.

Soil disturbance through plowing and harrowing is extremely beneficial to carry out soil correction in the first year of cultivation, providing the best development and effectiveness of the corrective.

The adoption of no tillage did not prove to be the best option for a first-year sugarcane cultivation, due to the difficulty to incorporate the corrective.

The soil preparation system consisted of liming + harrowing + plowing + harrowing (T3) showed the best results for all evaluated parameters.

RESUMO: Em área de expansão, onde se têm restrições quanto à fertilidade, o preparo do solo contribui consideravelmente para a melhoria das condições físicas, químicas e hídricas dos solos e, consequentemente, para o desenvolvimento adequado da cultura da cana-de-açúcar. O objetivo deste trabalho foi avaliar o efeito de diferentes técnicas de manejo, sobre a disponibilidade de nutrientes no solo, em área de expansão de cana-de-açúcar, anteriormente com a presença de Brachiaria decumbens, na região do cerrado. O experimento foi conduzido na usina Jalles Machado, em Goianésia, GO, sendo utilizada a variedade CTC 2. O experimento foi implantado em delineamento de blocos casualizados, com seis tratamentos e quatro repetições. Foram avaliados os atributos químicos do solo, nas profundidades de 0-20, 20-40 e 40-60 cm. Foram observadas diferenças significativas entre as profundidades para todos os atributos analisados. Os diferentes manejos adotados interferiram nos atributos químicos e na disponibilidade de nutrientes para as plantas. O revolvimento do solo através de aração e gradagem é extremamente benéfico para a realização da correção do solo para o primeiro ano de cultivo, tornando melhores a incorporação e eficácia do corretivo. A adoção do sistema plantio direto não demonstrou ser a melhor opção para o primeiro ano de cultivo de cana-de-açúcar, dificultando a incorporação dos corretivos utilizados.

PALAVRAS-CHAVE: Nutrição de plantas. Preparo do solo. Saccharum officinarum.

\section{REFERENCES}

ALVAREZ, V. H.; NOVAIS, R. F. de; BARROS, N. F. de; CANTARUTTI, R. B.; LOPES, A. S. Interpretação dos resultados das análises de solos. In: RIBEIRO, A. C.; GUIMARÃES, P. T. G.; ALVAREZ, V. H. Comissão de fertilidade do solo do Estado de Minas Gerais. Recomendações para o uso de corretivos e fertilizantes em Minas Gerais - 5 Aproximação. Viçosa, MG, p. 25 - 32.1999. 
ARRUDA, E. M.; ALMEIDA, R. F. DE; JUNIOR, A. C. DA S.; RIBEIRO, B. T.; SILVA, A. DE A.; LANA, R. M. Q. Aggregation and organic matter in different tillage systems for sugarcane. African Journal of Agricultural Research, v. 10, n. 4, p. 281-288. 2015. http://dx.doi.org/10.5897/AJAR2014.9259

BENEDINI, M. S.; CONDE, A. J. (2008). Sistematização de área para a colheita mecanizada da cana-deaçúcar. Revista Coplana - 23.

http://www.coplana.com/gxpfiles/ws001/design/RevistaCoplana/2008/Novembro/pag23-24-25.pdf.

BRASIL. 2015. Ministério da Agricultura, Pecuária e Abastecimento. Balança Comercial do Agronegócio. Edição 2015. Ministério da Agricultura, Pecuária e Abastecimento - Secretaria de Relações Internacionais do Agronegócio. Brasília, MAPA/ACS.

CANASAT - Mapeamento da cana via imagens de satélite de observação da Terra. INPE - Instituto Nacional de Pesquisas Espaciais. Disponível em: Acesso em 17 jun. 2014.

CASTELÕES, L. "Embrapa pesquisa cana-de-açúcar em área de expansão no Cerrado"; Empresa Brasileira de Pesquisa Agropecuária. Disponível em: https://www.embrapa.br/busca-de-noticias/-

/noticia/2454148/embrapa-pesquisa-cana-de-acucar-em-area-de-expansao-no-cerrado. Acesso em 26 mar. 2015.

CONAB. Acompanhamento da safra brasileira. Cana-de-açúcar, V. 1 - Safra 2014/15, n.2 - Segundo Levantamento, Brasília, p. 1-20, ago. 2014.

DUIKER, S. W.; BEEGLE, D. B. Soil fertility distributions in long-term no-till, chisel/disk

EMBRAPA - EMPRESA BRASILEIRA DE PESQUISA AGROPECUÁRIA. Manual de análises químicas de solos, plantas e fertilizantes. 2 ed. rev. e ampliada. Brasília, DF: Embrapa informação tecnológica. 627 p. 2009.

EMBRAPA - EMPRESA BRASILEIRA DE PESQUISA AGROPECUÁRIA. Sistema Brasileiro de classificação de Solos. 2 ed. Embrapa Solos. Rio de Janeiro, RJ. 306 p. 2006.

FOLTRAN, R. Aplicação de calcário, silicato e gesso em soqueira de cana-de-açúcar sem despalha a fogo. 111f. (2008). Dissertação (mestrado em Agronomia). Faculdade de Ciências Agronômicas da UNESP Campus de Botucatu, Botucatu - SP.

FORTES, C.; TRIVELIN, P. C. O.; VITTI, A. C. Long-term decomposition of sugarcane harvest residues in Sao Paulo state, Brazil. Biomass and bioenergy, v. 42, p. 189 - 198. 2012.

http://dx.doi.org/10.1016/j.biombioe.2012.03.011

INÁCIO, J. B.; SANTOS, R. J. A expansão canavieira no município de delta- MG: "ilhados pelos canaviais". Caminhos de Geografia, Uberlândia, v. 14, n. 48, p. 209-227. 2013.

KAMINSKI, J.; SILVA, L. S.; CERETTA, C. A.; RHEINHEIMER, D. Acidez e calagem em solos do sul do Brasil: aspectos históricos e perspectivas futuras. In: Ceretta C A, Silva L S, Reichert J, M. Tópicos em ciência do solo. - Vol. 1. Viçosa. MG: SBCS. p. 307-332. 2007.

LOPES, A. S.; WIETHÖLTER S.; GUILHERME L. R. G.; SILVA C. A. Sistema plantio direto: bases para o manejo da fertilidade do solo. Associação Nacional para Difusão de Adubos. São Paulo. 115p. 2004.

MORAES, E. Atributos químicos do solo e teor foliar de nutrientes em cana-de-açúcar sob diferentes formas de preparo de solo em área de reforma e expansão no cerrado . Uberlândia: UFU, 2011. 108p. Dissertação de Mestrado. 
NETO, A. E. F. et al. Fertilidade do solo. Curso de pós-graduação "Latu Sensu" (Especialização) à distância Fertilidade do solo e nutrição de plantas no agronegócio. Lavras: UFLA/FAEPE. 261p. 2001.

OKORKOV, V. V.; OKORKOVA, L. A. Interaction of lime and gypsum with sorption complex of acidic soils. Russian Agricultural Sciences, v. 39, n. 5, p. 459-463. 2013. http://dx.doi.org/10.3103/S1068367413060153

PAVINATO, P. S.; MERLIN, A.; ROSOLEM, C. A. Disponibilidade de cátions no solo alterada pelo sistema de manejo. Revista Brasileira de Ciência do Solo, v. 33, n. 4, 1031-1040. 2009.

http://dx.doi.org/10.1590/S0100-06832009000400027

RAIJ, B, van; CANTARELLA, H.; QUAGGIO, J. A.; FURLANI, A. M. C. Recomendações de adubação e calagem para o estado de São Paulo. 2 ed. Campinas. Instituto Agronômico e Fundação IAC, 285 p. 1996.

ROSSETTO, R.; DIAS F. L. F.; VITTI A. C. Cana de açúcar. 1 ed. Campinas. Instituto Agronômico, p. 221269. 2010.

SILVA, E. DE F.; MOITINHO, M. R.; TEIXEIRA, D. DE B.; PEREIRA, G. T.; JUNIOR, N. L. A. S. Emissão de $\mathrm{CO} 2$ do solo associada à calagem em área de conversão de laranja para cana-de-açúcar. Engenharia Agrícola, Jaboticabal, v. 34, n. 5, p. 885-898. 2014.

TRIVELIN, P. C. O.; BERDASSOLLI, J. A.; OLIVEIRA, M. W. Potencialidade da mistura de aquamônia com vinhaça na fertilização de canaviais colhidos sem despalha a fogo: Estabilidade química da mistura. STAB Açúcar, Álcool Subpr., v. 16, p. 26-29. 1997.

VITTI, G. C.; MAZZA, J. A. Planejamento, estratégias de manejo e nutrição da cultura de cana-deaçúcar. Piracicaba: Potafos, (Encarte técnico/Informações agronômicas, 97). 16p. 2002. 